\section{LA to Vegas in 75 minutes}

San Francisco \& Munich

AfTER years of development in several countries, the world's first long-distance magnetically levitated train (maglev) appears to be on the way to reality by 1997 in the western United States.

Although short prototype maglev lines have been in operation in West Germany and Japan for several years, a 427-km passenger line between the Los Angeles area and Las Vegas, Nevada, using German train technology, will be the first truly commercial venture of its type.

The go-ahead came two weeks ago when the California-Nevada Super Speed Train Commission awarded a franchise for construction of the maglev line to a consortium led by Bechtel International, a large engineering concern, of San Francisco. Transrapid International of West Germany will provide maglev technology in what is its first commercial contract. Approval of the franchise is being termed "tentative", but both the consortium and the commission are confident that final approval will be granted in the next few months. Construction should then begin in 1993

Bechtel expects a total cost of $\$ 5,000$ million for the line, which will run to Las Vegas from Anaheim, in the Los Angeles metropolitan area. The line will be financed solely through private investors. Other consortium members include the $\mathrm{C}$. Itoh Company of Japan, which is expected to act as a lead representative for Japanese investors, and Amtrak, the US passenger rail operator, which will provide operations, maintenance and marketing services.

In Transrapid's maglev technology, a U-shaped track carries a varying electromagnetic field that acts on conventional magnets underneath and along the sides of the train, supporting it and drawing it along. In contrast, the Japanese maglev system uses superconducting magnets, but is not yet ready for commercial use because, according to Bechtel vicepresident Erv Koenig, a method to shield passengers from the very strong magnetic field has not yet been developed.

The Bechtel and Transrapid teams are also ready to proceed by November on construction of a short maglev line in Florida, which will run from Orlando to Disney World. Despite the US selection of its system, Transrapid still sees the Japanese alternative as a "very serious competitor", according to Thomas Naujoks of Thyssen Henschel, leader of the Transrapid consortium.

Transrapid has had less success at home: it has not yet found funding to build a 55-km test track which was approved last December to run between Düsseldorf and the Cologne-Bonn airport.

Journey time between Las Vegas and
Anaheim is estimated at only 75 minutes, the trains maintaining speeds of over 500 $\mathrm{km}$ per hour for most of the distance. Its developers claim the train will make only about as much sound as an automobile as it passes, and that the electric powered maglev will replace 620,000 automobilekilometres each year, equivalent to a reduction of tons of smog-causing nitrogen oxide emissions.

The US line will be based on a prototype train currently operated by Transrapid on a $31.5-\mathrm{km}$ test track in Emsland, West Germany. That train logged 100,000 $\mathrm{km}$ this month, and data generated from test runs are now being examined by German and US railway regulatory officials. Koenig says he expects the certification required for construction to be made by 1 October.

This latest date and details of Bechtel's

\section{Washington}

SCIENTISTS at the Massachusetts Institute of Technology (MIT) may have lost a surebet \$118-million magnet laboratory last week, but they did get a valuable lesson in the politics of science funding. To wit: money talks, and $\$ 58$ million talks very loudly.

Painful proof arrived on 17 August, when the National Science Foundation (NSF), with the blessing of its National Science Board, chose Florida State University as the future site of the National High Magnetic Field Laboratory (NHMFL), a user facility that will produce the world's most powerful steady magnetic fields by the time of its completion in 1996. Two independent review panels had picked MIT (whose Francis Bitter Laboratory is the leading US steady-state magnetic field facility) as the better of the two sites, but when the state of Florida sweetened its pot with a \$58-million matching offer, NSF found it hard to say no.

"Our responsibility is to get the biggest bang for the buck", explains David Sanchez, NSF's assistant director for mathematical and physical science. MIT was able to offer industrial contributions of only about $\$ 10$ million to the project. Sanchez notes that, although the scientific review panels favoured MIT, they also concluded that "the US would be well served by either proposal". Although Florida State has no existing magnet facility, it has arranged a partnership with the Los Alamos National Laboratory and the French Grenoble Magnet Laboratory, both of which have world-class magnet programmes. The university has also promised to create 54 new faculty and staff financial feasibility studies will be presented to the commission at their next meeting. Both sides indicate they expect negotiations of the conditions for final approval to go smoothly and to be completed within two to four months.

Bechtel officials have presented their maglev plan to several environmental groups already, and have encountered no serious opposition. Construction plans call for the train to run beside an existing major highway, so no new environmental disruption will occur. The tracks are to be elevated and supported by pillars so that the natural environment can reestablish itself between supports.

Commission chairman Arnie Adamsen expects the largest segment of the train's ridership to consist of tourists, with "recreational" riders and commuters providing additional passengers. The roundtrip fare is likely to be $\$ 110$ at present prices, 30 per cent less than airline fares.

Elizabeth Schaefer \& Steven Dickman

\title{
Economics lesson for MIT
}

positions for the laboratory. Sanchez expects that in five years Florida State will be at the same point the MIT laboratory would have been and will have surpassed the predicted MIT position within ten years.

NHMFL will be the United States' top magnet laboratory, and is to feature a direct-current magnet generating a field of 45 tesla, almost 10 tesla higher than the current world record (held by MIT). Intense magnetic fields can be used to explore the structure of complex biological molecules, and to create new materials.

Paul Gray, president of MIT, released a statement last week announcing that the university will ask NSF to reconsider the decision, and is filing an appeal based on scientific and procedural arguments. Although Sanchez says NSF will consider any request, he points out that all the National Science Board did was to approve an internal NSF decision to pick Florida State. There is no formal appeal process for the decision. Sanchez says that NSF will continue funding the Francis Bitter Laboratory for at least one more year at a level of $\$ 6$ million.

The NSF decision is seen as a sign of a growing trend towards pragmatism in an increasingly tight fiscal climate. "First Texas buys the SSC [Superconducting Super Collider]and now Florida buys the magnet facility. Is this going to be the rule in the future?" ask Robert Park, director of the American Physical Society's Washington office. Park is concerned that universities that are not part of a consortium or do not have substantial state support may find it increasingly difficult to win large projects. Chrlstopher Anderson 